DEPARTMENT OF THE INTERIOR

U.S. GEOLOGICAL SURVEY

\title{
Principal Facts for 64 Gravity Measurements in the vicinity of Beardmore Glacier, McMurdo Station, and CASERTZ Field Camp, Antarctica
}

\author{
by
}

R.W. Saltus ${ }^{1}$, G. Perasso ${ }^{1}$, K. Covert $^{1}$, M. Hower ${ }^{1}$, and R.P. Kucks ${ }^{1}$

Open-File Report 92-322

This report is preliminary and has not been reviewed for conformity with U.S. Geological Survey editorial standards or conformity with the North American Stratigraphic Code. Any use of trade, firm, or product names is for descriptive purposes only and does not imply endorsement by the U.S. Government.

${ }^{1}$ Denver, Colorado 


\section{Abstract}

This report describes data for 64 gravity measurements made during three field seasons in Antarctica. In 1985-1986, 19 measurements were made in McMurdo and in the vicinity of the Beardmore field camp. In 1986-1987, 34 measurements were made in McMurdo and in the vicinity of the Dry Valleys. In 1991-1992, 11 measurements were made in McMurdo and in the vicinity of the CASERTZ field camp. The measurements were made by U.S. Geological Survey personnel with Lacoste and Romberg gravity meters G-17, G191, and G192. Elevation control is from Doppler, vertical angle, and GPS satellite positioning. Tables in this report list principal facts and reduced free-air and simple Bouguer (no ice correction applied) anomalies on the IGSN 71 datum. Page-sized plots show the measurement site locations and locations of previous gravity measurements in the same regions.

\section{Gravity Data Collection}

The gravity measurements in this report were made in three field seasons, 1985-86, 1986-87, and 1991-92 (Fig. 1). In the first two seasons, gravity data were collected in conjunction with U.S. Geological Survey geodetic control surveys. During the 1991-92 season, gravity measurements were made to provide base ties for the CASERTZ (Corridor Aerogeophysics of the Southeast Ross Transect Zone) airborne geophysical survey.

\section{5-86 field season}

In the 1985-86 season, Gary Perasso and Marguerite Hower (both with U.S. Geological Survey, National Mapping Division) made measurements with Lacoste and Romberg meters G-17 and G-192 in the vicinity of the Beardmore glacier camp and at selected horizontal traverse stations to the north, terminating in an area on the Nimrod glacier (Fig. 2). Previous gravity measurement locations and free air anomalies in the same vicinity (from the Defense Mapping Agency (DMA) data set on the National Geophysical Data Center CD-ROM (Hittelman, et al., 1992)) are shown on Figure 3. The main base station for this work was the benchmark "SEISMIC" in the back of the Thiel Earth Sciences Laboratory. The field base was the station "BEARD" on the Bowden Neve at the Beardmore South Field Camp. The Beardmore base station was a wooden platform inside a Hex tent set in the snow. The field base station was tied to the McMurdo base with four one-way ties, one with each meter at the beginning and end of the field season. The gravity measurements were taken at USGS triangulation stations reached by helicopter from Beardmore camp. The sites are on rock in mountainous regions and are monumented with USGS benchmarks (complete benchmark names are given in the Appendix). Elevations are from processed geodetic control data based on Doppler and vertical angle traverses (James E. Stoner, USGS National Mapping Division, personnal communication, March 1988).

\section{6-87 field season}

In the 1986-87 season, Kathy Covert (U.S. Geological Survey, National Mapping Division) made measurements with Lacoste and Romberg meter G-17 in the vicinity of McMurdo station and the Dry Valleys (Fig. 4). Previous gravity measurement locations and free air anomalies in the same vicinity (from the DMA gravity data base, Hittelman et al., 1992) are plotted on Figure 5. The main base station for this work was the benchmark "SEISMIC" in the back of the Thiel Earth Sciences Laboratory. The gravity measurements were taken at USGS triangulation stations reached by helicopter from McMurdo Station. The sites are on rock in mountainous regions and are monumented with USGS benchmarks (complete benchmark names given in the Appendix). Elevations are from processed geodetic control data based on Doppler and vertical angle traverses. (James E. Stoner, USGS National Mapping Division, personnal communication, March 1988). 


\section{1-92 field season}

In the 1991-92 season, Richard Saltus and Robert Kucks (U.S. Geological Survey, Geologic Division, Branch of Geophysics) made measurements with Lacoste and Romberg meter G-191 at several sites surrounding the CASERTZ base camp (Fig 6). Previous gravity measurement locations and free air anomalies in the same vicinity (from the DMA gravity data base, Hittleman et al., 1992) are plotted in Figure 7. The main base station for this work was the concrete slab in the gravity base station hut at McMurdo (Building 57 - sometimes called "Hugo's hut"). The field base station was the site "CTZ" on a wooden pier embedded in the snow. This base was tied to the McMurdo base with two one-way ties, one at the beginning and one at the end of the field season. The "CTZUP" site was at the initial height of the base pier before it was cut off at floor level in the "Science Jamesway" hut at CASERTZ camp. The "CTZ" site was several feet higher than the base station site for the 1990-91 CASERTZ camp (because of snow accumulation between the two seasons). The "NVR" sites were at the locations of remote navigation beacons set up for the 1991-92 aerogeophysical survey. These beacons were removed at the end of the field season. The sites were reached with ski-equipped aircraft (DeHaviland Twin Otter). Elevation and position control is from a Global Positioning System (GPS) survey by the Naval Research Laboratory (James Jarvis, Naval Research Laboratory, personnal communication, 1991).

\section{Gravity Data Reduction}

Observed gravity values were obtained from the gravity meter readings using the calibration tables provided by Lacoste and Romberg for each gravity meter. Secondary calibration factors, as determined by USGS calibration, of 1.00252 for G-17 and 1.000412 for G-192 were used in addition to the factory calibration tables. Gravity meter drift was modeled by a splined curve through the base station readings for each entire season for each meter. Typical daily drift rates observed were about $0.01 \mathrm{mGal} /$ hour and base stations were visited about once a day during surveys, so average errors of about $0.1 \mathrm{mGal}$ are expected in the observed gravities reported here.

Bouguer gravity anomalies were calculated using the 1967 Geodetic Reference System formula (International Association of Geodesy, 1971) using Branch of Geophysics software (methods as described in Cordell et al., 1982) modified for use in Antarctica. The measurements are tied to International Gravity Standardization Network of 1971 (IGSN 71, Morelli, 1974) values for base stations "SEISMIC" (at Thiel Laboratory) and "BLD57" (at Building 57) at McMurdo Station. The assumed values for these base stations are given in table 1 (values from Charles Bentley, University of Wisconsin, personnal communication). A Bouguer reduction density of $2.67 \mathrm{~g} / \mathrm{cm}^{3}$ was used to calculate the simple Bouguer anomalies. An Earth curvature correction is included in the simple Bouguer anomaly. No attempt has been made to make terrain corrections or ice thickness corrections to these data. Terrain corrections are likely to exceed $10 \mathrm{mGal}$ in some of the mountainous sites.

Table 1: IGSN 71 Base Station Values at McMurdo Station

\begin{tabular}{llrrrrrr}
\multirow{2}{*}{ Station } & \multirow{2}{*}{ Location } & \multicolumn{2}{c}{ Latitude } & \multicolumn{2}{c}{ Longitude } & Elevation & Obs. Gravity \\
& & deg & min & deg & min & meters & mGal \\
\hline SEISM & Benchmark behind Thiel Lab & -77 & 53.11 & 166 & 45.30 & 47 & $982,969.85$ \\
BLD57 & Building 57 - "Hugo's Hut" & -77 & 50.86 & 166 & 40.47 & $\mathbf{3 5}$ & $\mathbf{9 8 2 , 9 7 2 . 7 2}$
\end{tabular}

The lack of ice thickness corrections is particularly important for the 1991-92 data set in the CASERTZ vicinity. Previous gravity data from over-snow traverses typically contain an ice correction to the simple Bouguer anomaly, so the Bouguer values given here will be much lower than the older data. When ice thickness estimates have been computed from the airborne radar collected during the CASERTZ 1991-92 
season, these corrections will be made. Data from the 1985-86 and 1986-87 seasons were collected on rock sites, so the lack of ice correction is justified for those data.

\section{Gravity Data Table}

The gravity data table contains the principal facts and reduced gravity anomalies for the three surveys. The station name is a five-letter abbreviation, complete station names for USGS triangulation sites are given in the Appendix. Latitudes and longitudes are reported in degrees and minutes to the nearest hundredth of a minute. Elevations are given in both feet and meters. Gravity anomalies are reported in $\mathrm{mGals}(1 \mathrm{mGal}=$ $10^{-5} \mathrm{~m} / \mathrm{s}^{2}$ ) to the nearest hundredth. $O G$ is observed gravity, $F A A$ is free air anomaly, and $S B A$ is simple Bouguer anomaly. The last column of the table, $n$, is the number of readings averaged in the reported value; $a^{\text {'*' }}$ in that column indicates a base station.

Table 2: Gravity Measurements in the Vicinity of McMurdo Station, Beardmore Glacier, and CASERTZ field camp

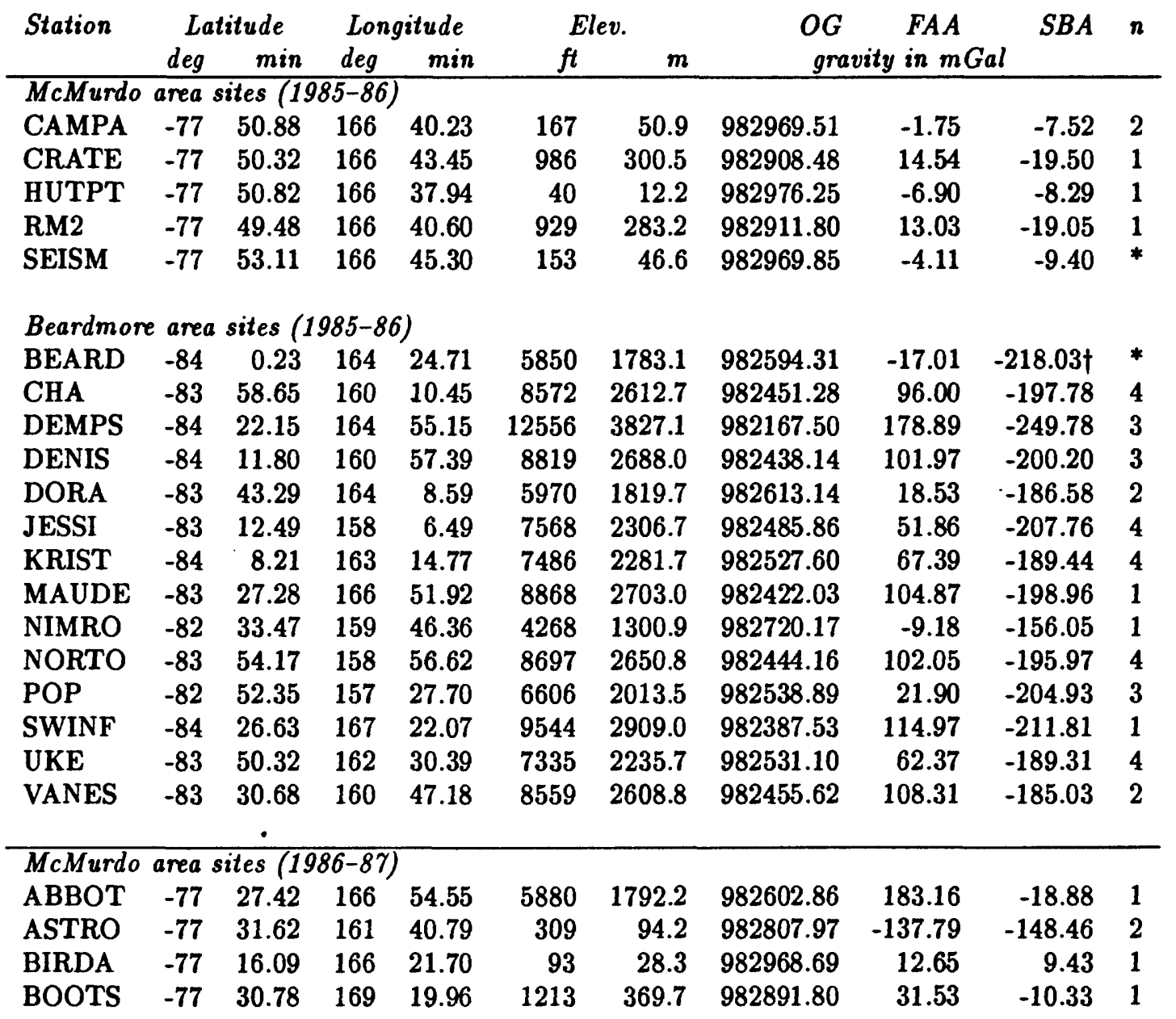

$\dagger=$ ice correction needed. 
Table 2 - continued

\begin{tabular}{|c|c|c|c|c|c|c|c|c|c|c|}
\hline \multirow[t]{2}{*}{ Station } & \multicolumn{2}{|c|}{ Latitude } & \multicolumn{2}{|c|}{ Longitude } & \multicolumn{2}{|c|}{ Elev. } & \multirow{2}{*}{\multicolumn{2}{|c|}{$\begin{array}{l}O G \quad F A A \\
\text { gravity in } m G o\end{array}$}} & \multirow{2}{*}{$S B A$} & \multirow[t]{2}{*}{$\mathbf{n}$} \\
\hline & deg & $\min$ & deg & $\min$ & $f t$ & $m$ & & & & \\
\hline \multicolumn{11}{|c|}{ McMurdo area sites (1986-87) - continued } \\
\hline BRATI & -78 & 0.35 & 165 & 33.10 & 105 & 32.0 & 982960.31 & -22.65 & -26.27 & 1 \\
\hline BROWN & -77 & 30.06 & 169 & 3.01 & 4471 & 1362.8 & 982688.74 & 135.02 & -18.80 & 1 \\
\hline CAMPA & -77 & 50.88 & 166 & 40.23 & 167 & 50.9 & 982969.10 & -2.17 & -7.94 & 1 \\
\hline CRASH & -77 & 26.68 & 167 & 33.53 & 2833 & 863.5 & 982809.58 & 104.16 & 6.53 & 1 \\
\hline DEB & -77 & 16.29 & 166 & 44.74 & 5901 & 1798.6 & 982588.86 & 178.33 & -24.43 & 1 \\
\hline HENDE & -78 & 17.58 & 166 & 19.42 & 1116 & 340.2 & 982935.85 & 37.40 & -1.12 & 1 \\
\hline HERB & -77 & 43.56 & 163 & 52.68 & 3603 & 1098.2 & 982689.57 & 45.75 & -78.32 & 2 \\
\hline HOGBA & -77 & 29.10 & 163 & 36.57 & 2407 & 733.7 & 982772.86 & 25.86 & -57.12 & 1 \\
\hline HUTPT & -77 & 50.82 & 166 & 37.94 & 40 & 12.2 & 982976.17 & -6.98 & -8.36 & 1 \\
\hline JOEBM & -77 & 50.54 & 166 & 43.79 & 729 & 222.2 & 982978.66 & 60.43 & 35.25 & 1 \\
\hline KELLI & -77 & 22.58 & 168 & 5.79 & 166 & 50.6 & 982986.96 & 33.57 & 27.84 & 1 \\
\hline KELME & -76 & 58.40 & 166 & 54.42 & 8 & 2.4 & 982977.10 & 24.70 & 24.42 & 1 \\
\hline KEVIN & -78 & 11.12 & 167 & 29.80 & 1674 & 510.2 & 982899.87 & 57.77 & 0.03 & 1 \\
\hline MARY & -78 & 17.20 & 163 & 31.23 & 575 & 175.3 & 982966.46 & 17.41 & -2.45 & 1 \\
\hline MELAN & -78 & 8.05 & 166 & 7.87 & 698 & 212.8 & 982971.03 & 39.08 & 14.98 & 1 \\
\hline MILLS & -77 & 56.20 & 164 & 4.83 & 4056 & 1236.3 & 982689.81 & 80.65 & -58.96 & 4 \\
\hline MWISE & -78 & 7.84 & 165 & 22.99 & 2684 & 818.1 & 982813.11 & 67.91 & -24.59 & 1 \\
\hline NSFCH & -77 & 50.89 & 166 & 40.16 & 94 & 28.7 & 982973.60 & -4.53 & -7.78 & 1 \\
\hline PAT & -78 & 0.99 & 167 & 24.99 & 139 & 42.4 & 983004.15 & 24.00 & 19.20 & 1 \\
\hline PKING & -78 & 33.08 & 164 & 21.53 & 4253 & 1296.3 & 982702.89 & 89.95 & -56.41 & 1 \\
\hline REPEA & -77 & 30.35 & 162 & 37.09 & 5903 & 1799.2 & 982484.10 & 64.67 & -138.15 & 1 \\
\hline SBAST & -77 & 50.99 & 166 & 45.76 & 52 & 15.8 & 982976.62 & -5.52 & -7.32 & 2 \\
\hline SBUSA & -77 & 50.95 & 166 & 45.39 & 112 & 34.1 & 982973.21 & -3.25 & -7.12 & 1 \\
\hline SCALL & -78 & 12.05 & 166 & 44.42 & 633 & 192.9 & 982977.96 & 37.47 & 15.61 & 1 \\
\hline SEISM & -77 & 53.11 & 166 & 45.30 & 153 & 46.6 & 982969.85 & -4.11 & -9.40 & * \\
\hline SPOLE & -90 & 0.00 & 180 & 0.00 & 9270 & 2825.5 & 982312.96 & -34.15 & $-351.64 \dagger$ & 2 \\
\hline STONR & -77 & 26.38 & 168 & 19.48 & 4529 & 1380.4 & 982704.25 & 158.34 & 2.53 & 2 \\
\hline TANKR & -77 & 50.91 & 166 & 41.54 & 206 & 62.8 & 982967.17 & -.44 & -7.56 & 1 \\
\hline TERRA & -77 & 30.43 & 167 & 55.10 & 6369 & 1941.3 & 982584.83 & 209.12 & -9.62 & 1 \\
\hline VINCE & -77 & 26.75 & 166 & 25.96 & 57 & 17.4 & 982963.61 & -2.71 & -4.68 & 1 \\
\hline \multicolumn{11}{|c|}{ McMurdo area sites (1991-92) } \\
\hline BLD57 & -77 & 50.86 & 166 & 40.47 & 115 & 35.1 & 982972.72 & -3.41 & -7.38 & * \\
\hline HUTPT & -77 & 50.82 & 166 & 37.94 & 40 & 12.2 & 982976.14 & -7.01 & -8.40 & 1 \\
\hline THIEL & -77 & 51.04 & 166 & 40.06 & 151 & 46.0 & 982970.28 & -2.58 & -7.80 & 3 \\
\hline \multicolumn{11}{|c|}{ CASERTZ area sites (1991-92) } \\
\hline CALIB & -82 & 21.75 & -118 & 9.57 & 3327 & 1014.1 & 982788.97 & -24.15 & $-138.75 \dagger$ & 1 \\
\hline CTZ & -82 & 21.57 & -118 & 7.84 & 3445 & 1050.0 & 982780.72 & -21.24 & $-139.88 \dagger$ & * \\
\hline CTZUP & -82 & 21.57 & -118 & 7.84 & 3448 & 1051.0 & 982780.52 & -21.17 & $-139.91 \dagger$ & 2 \\
\hline NVR1 & -81 & 22.86 & -112 & 17.71 & 5650 & 1722.1 & 982582.99 & 13.03 & $-181.15 \dagger$ & 1 \\
\hline NVR2 & -82 & 18.65 & -109 & 25.19 & 5797 & 1766.9 & 982551.40 & -28.49 & $-227.69 \dagger$ & 1 \\
\hline NVR3 & -83 & 22.03 & -109 & 56.16 & 5489 & 1673.0 & 982653.17 & 20.30 & $-168.07 \dagger$ & 1 \\
\hline NVR4 & -84 & 6.62 & -115 & 21.53 & 4505 & 1373.1 & 982765.11 & 25.48 & $-129.52 \dagger$ & 2 \\
\hline NVR6 & -82 & 10.36 & -116 & 39.26 & 3852 & 1174.1 & 982727.46 & -31.76 & $-164.37 t$ & 1 \\
\hline
\end{tabular}




\section{References}

Cordell, Lindrith, Keller, G.R., and Hildenbrand, T.G., 1982, Bouguer gravity map of the Rio Grande Rift, Colorado, New Mexico, and Texas: U.S. Geological Survey Geophysical Investigations Map GP-949,

Hittelman, A.M., Haberman, R.E., Dater, D.T., and Di, Liping, 1992, Gravity Earth System Data CDROM, Alpha Release, National Geophysical Data Center, 325 Broadway, Boulder, CO 80303-3328.

International Association of Geodesy, 1971, Geodetic Reference System 1967: International Association of Geodesy Special Publication, 116 p.

Morelli, C., 1974, The international gravity standardization net 1971: International Association of Geodesy Special Publication 4, $194 \mathrm{p}$. 


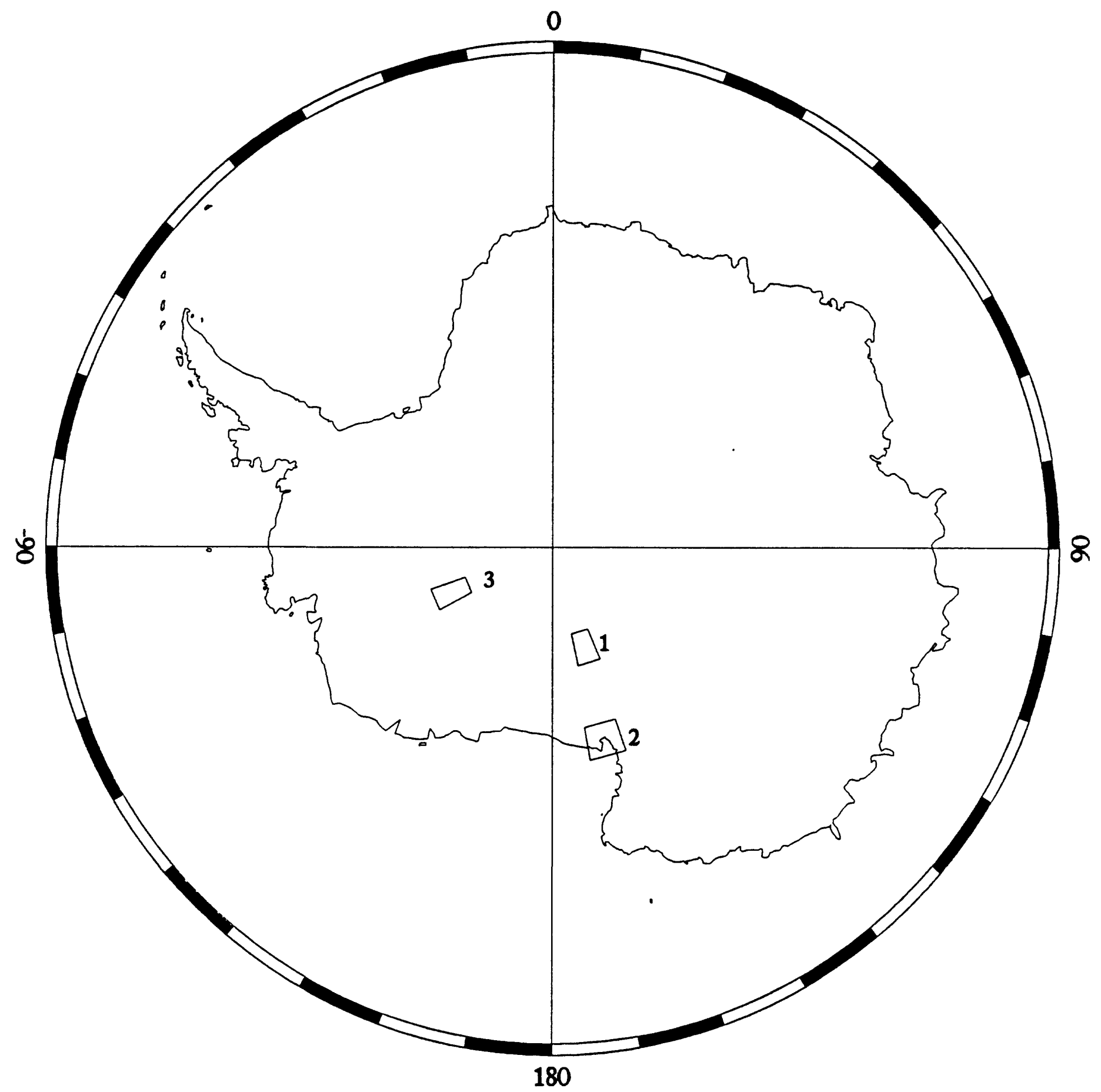

Figure 1: Location of gravity surveys in Antarctica. 1 = Beardmore vicinity survey (1985-86), 2 = McMurdo vicinity survey (1986-87), 3 = CASERTZ survey (1991-92). 


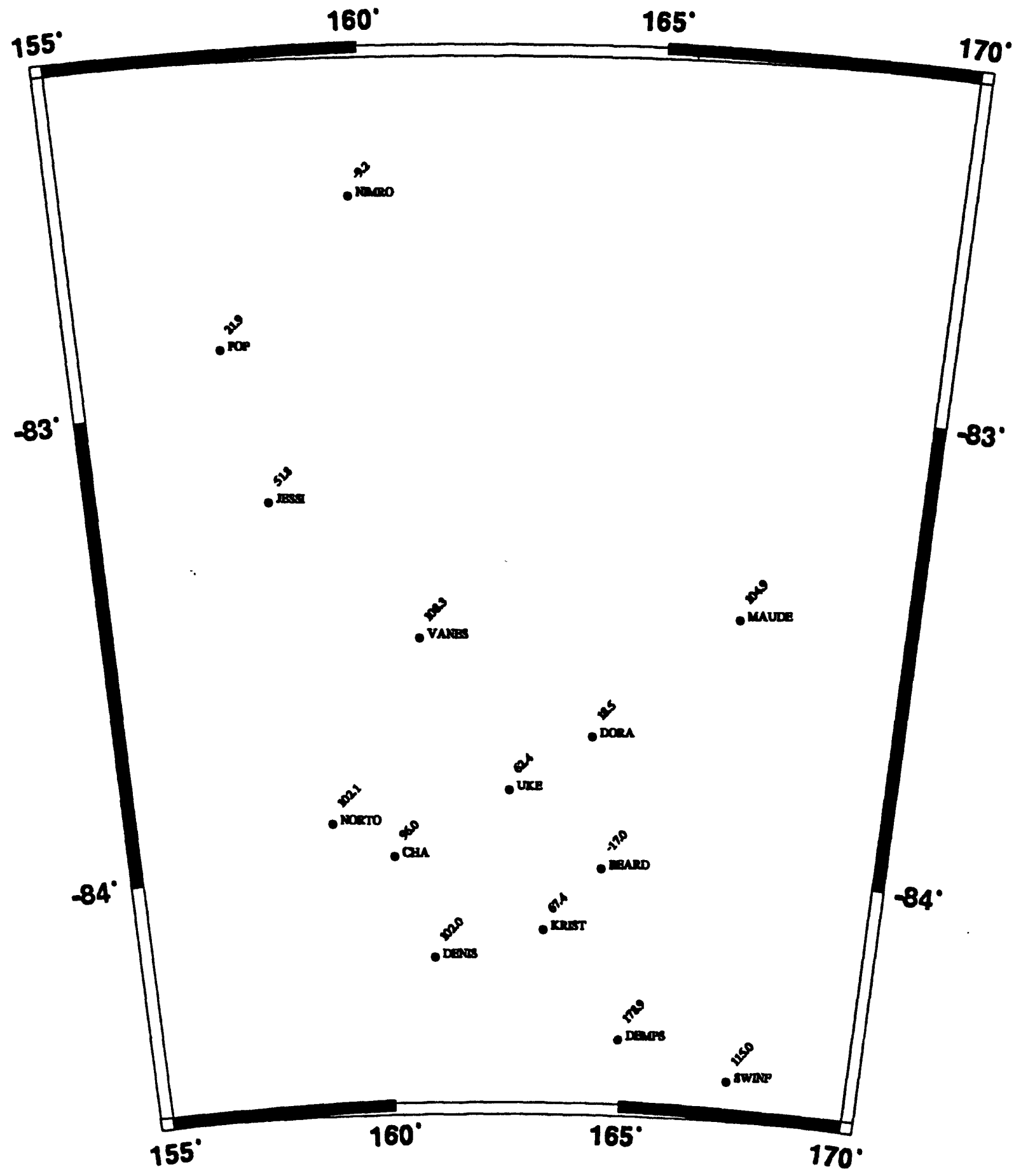

Figure 2: Gravity measurement sites in the Beardmore vicinity. Values are free air anomalies in mGal. 


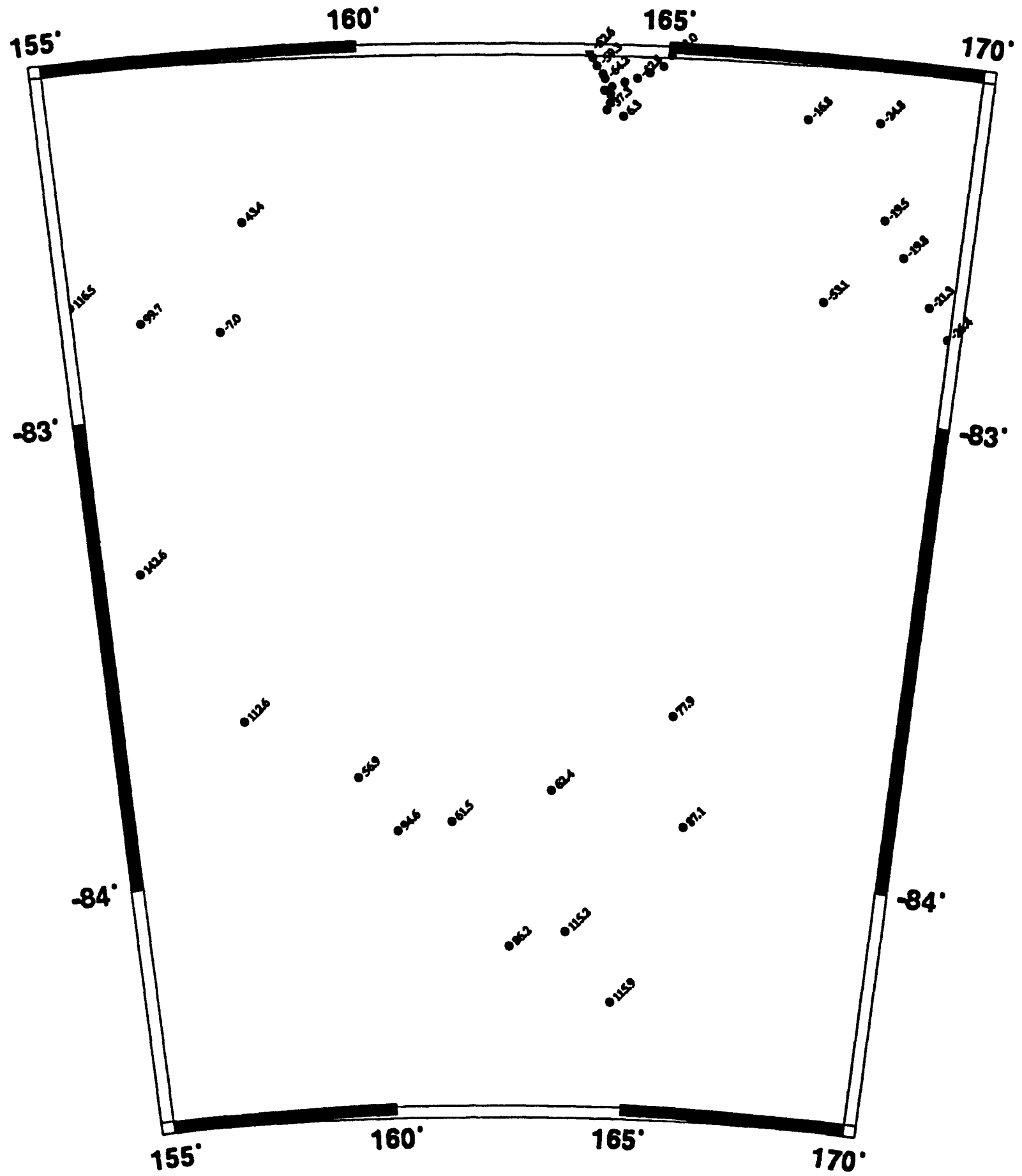

Figure 3: Previous gravity measurements in the Beardmore vicinity from the DMA gravity data base. Values plotted are free air anomalies in $\mathrm{mGal}$. 


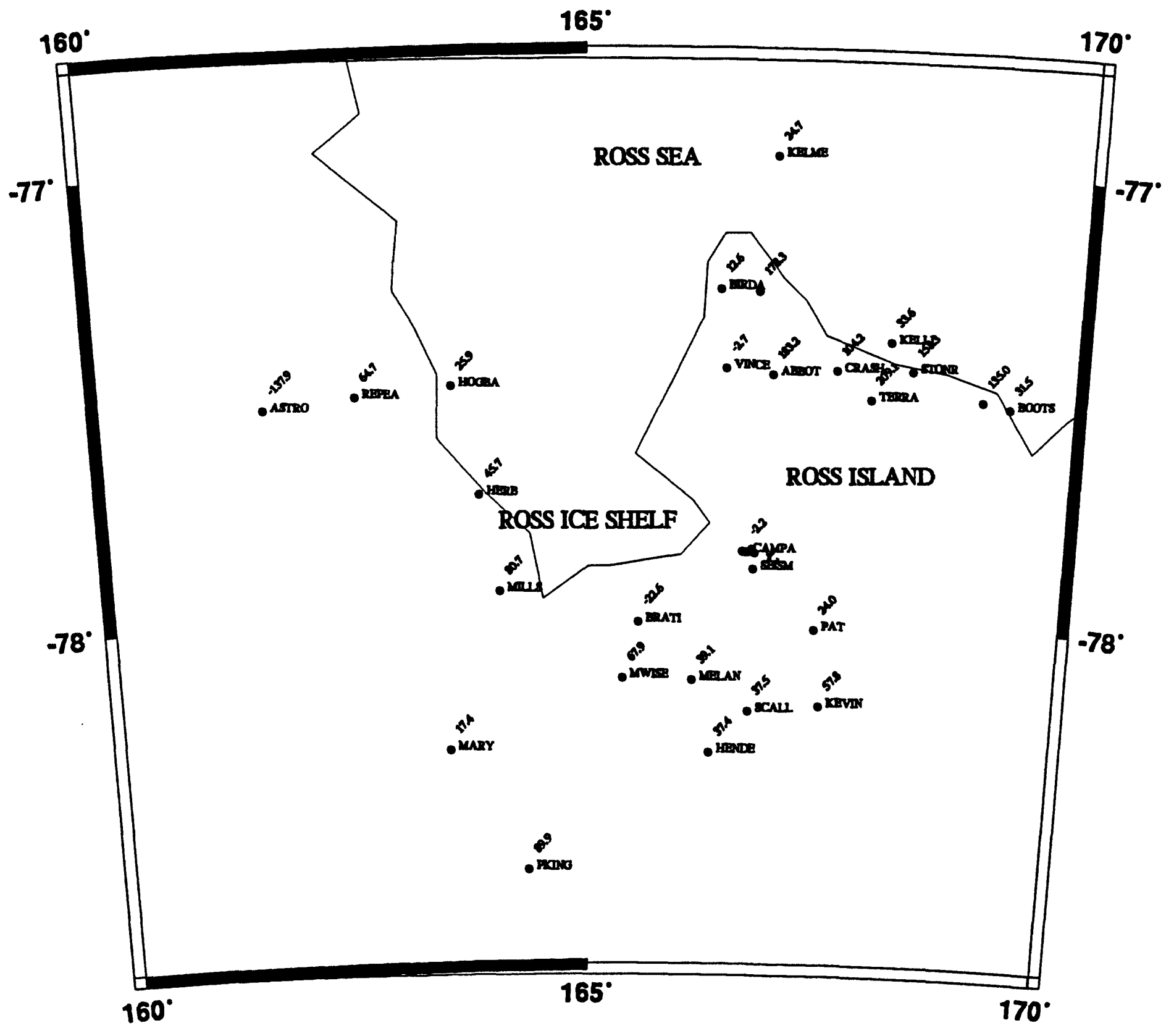

Figure 4: Gravity measurement sites in the McMurdo vicinity. Values are free air anomalies in mGal. 


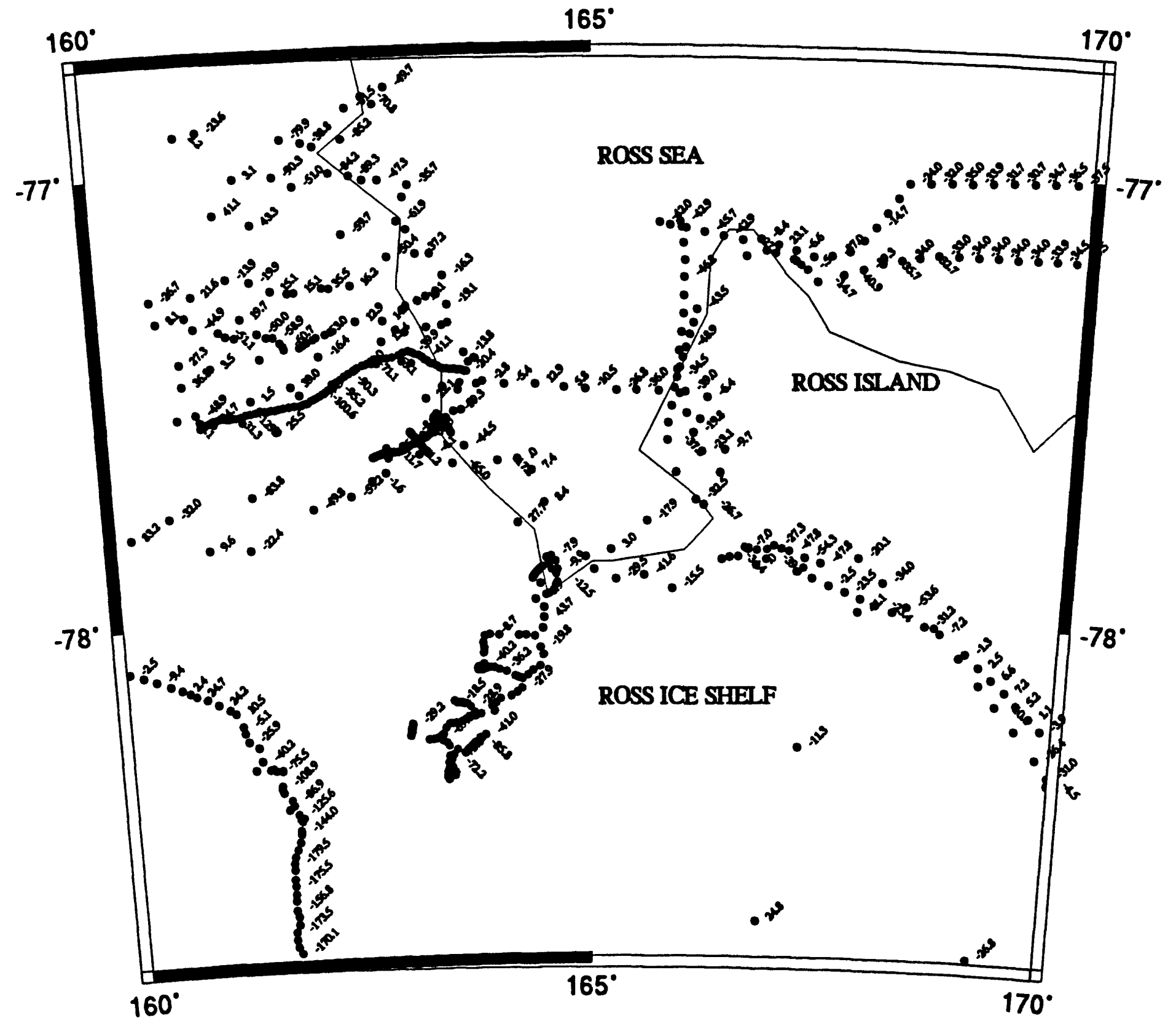

Figure 5: Previous gravity measurements in the McMurdo vicinity from the DMA gravity data base. Values plotted are free air anomalies in $\mathrm{mGal}$. 


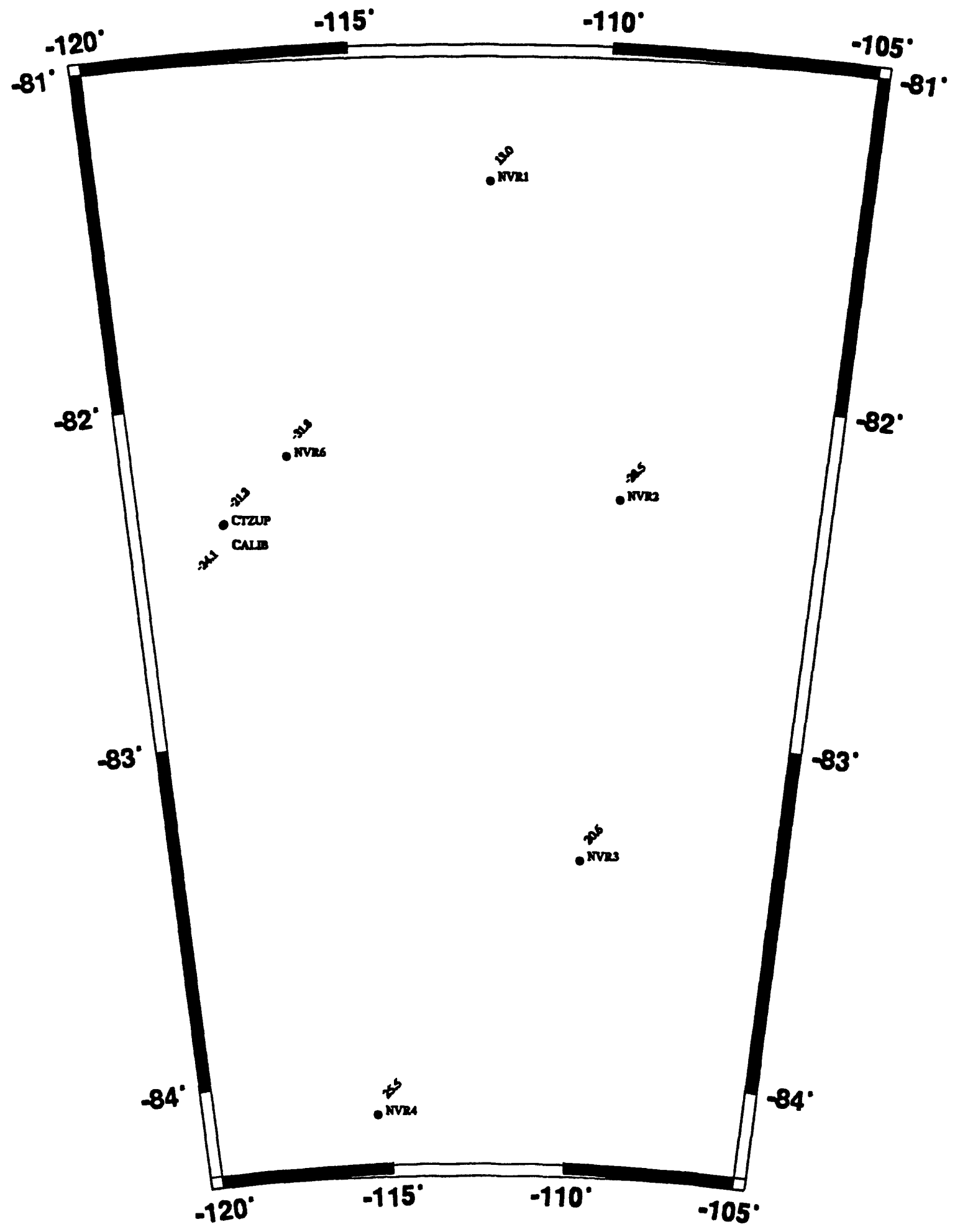

Figure 6: Gravity measurement sites in the CASERTZ vicinity. Values are free air anomalies in mGal. 


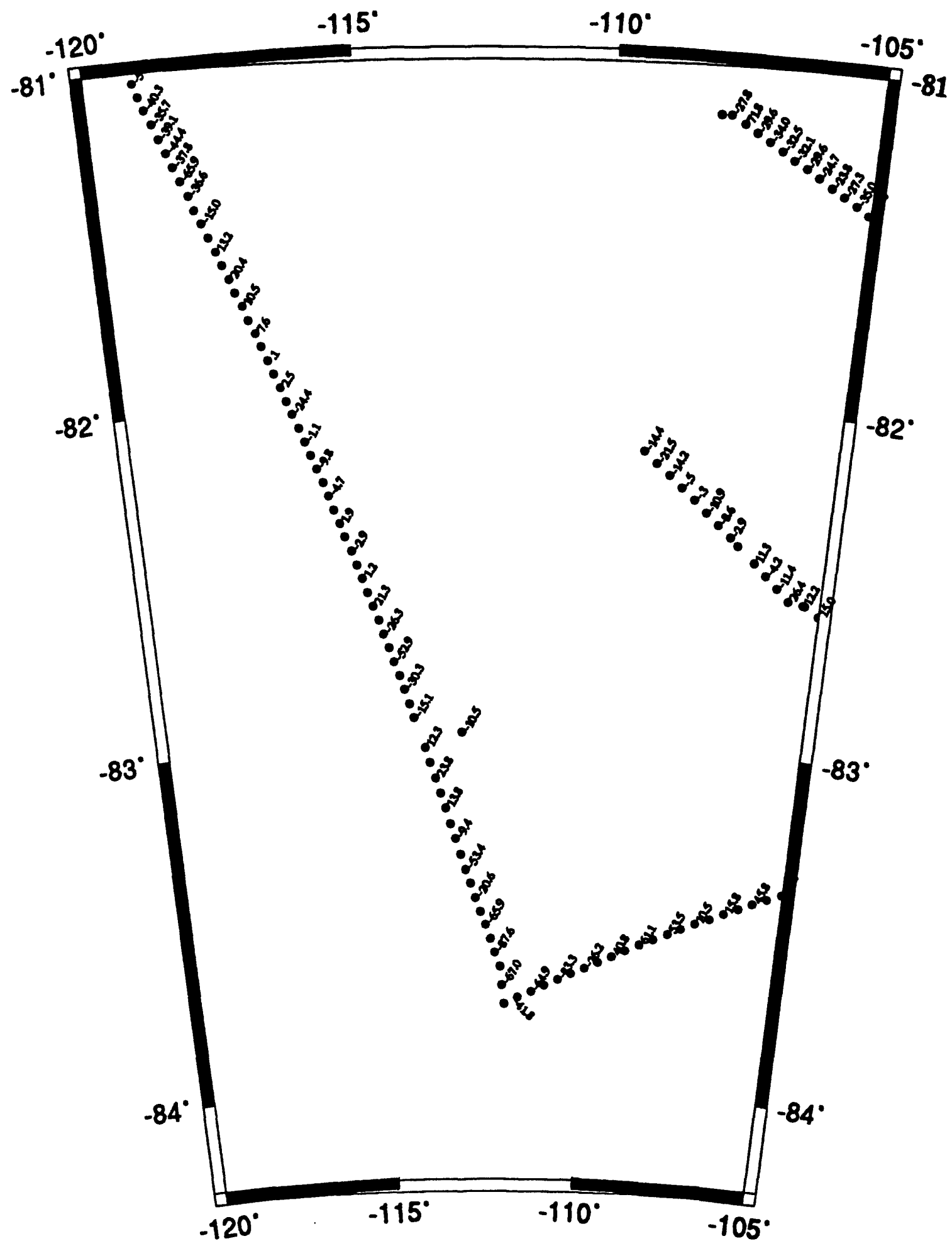

Figure 7: Previous gravity measurements in the CASERTZ vicinity from the DMA gravity data base. Values plotted are free air anomalies in $\mathrm{mGal}$. 


\section{Appendix - USGS Triangulation Station Names}

The gravity data table contains five-letter abbreviations of the complete station names. The following table contains the complete designation as stamped on the USGS triangulation station benchmark.

Complete USGS Triangulation Station Names

\begin{tabular}{|c|c|c|c|}
\hline Site name & Complete triangulation station name & Site name & Complete triangulation station name \\
\hline$\overline{\mathrm{ABBOT}}$ & ABBOTT ECC 1986-87 & MARY & MARY $1986-87$ \\
\hline ASTRO & VANDA ASTRO “A” NZARP & MAUDE & MAUDE (on Mt. Allen Young, not Mt. Maude) \\
\hline BIRDA & CAPE BIRD “A" ECC-NZARP & MELAN & MELANIA $1986-87$ \\
\hline BOOTS & BOOTS $1964-65$ & MILLS & MILLS ECC $1986-87$ \\
\hline BRATI & BRATINA $1986-87$ & MWISE & MT WISE NO 2 ECC (NZARP) \\
\hline BROWN & BROWN 1986-87 & NIMRO & NIMROD (on Kon-tiki Nunataks) \\
\hline CAMPA & CAMP AREA $1961-62$ & NORTO & NORTON 1985-1986 \\
\hline CHA & CHA $1985-86$ & NSFCH & NSF CHALET $1986-87$ \\
\hline CRASH & CRASH 1986-87 & PAT & PAT 1986-87 \\
\hline CRATE & CRATER HILL - JAN 1956 & PKING & PEAK-ING 1983-84 \\
\hline DEB & DEB-MT BIRD 1964-65 & POP & POP $1985-1986$ \\
\hline DEMPS & DEMPSEY $1985-86$ & REPEA & REPEATER ECC 1986-87 \\
\hline DENIS & DENISE 1985-86 & RM2 & SECOND CRATER RM \#2 \\
\hline DORA & DORA $1985-86$ & SBAST & SCOTT BASE ASTRO-NZARP \\
\hline HENDE & HENDERSON 1986-87 & SBUSA & SCOTT BASE USAF GRAVITY \\
\hline HERB & HERB ECC $1986-87$ & SCALL & SCALLOP $1986-87$ \\
\hline HOGBA & HOGBACK TOPO NORTH \#2 & SEISM & MCMURDO GRAVITY DISC \# 59676C \\
\hline HUTPT & HUT RESET 1964-65 & SPOLE & SOUTH POLE (actual site unknown) \\
\hline JESSI & JESSICA 1985-1986 & STONR & STONER 1986-87 \\
\hline JOEBM & JOES TIDAL BM $1986-87$ & SWINF & SWINFORD \\
\hline KELLI & KELLI $1986-87$ & TANKR & TANK RESET $1974-75$ \\
\hline KELME & KELMELIS $1986-87$ & TERRA & TERRA NOVA $1986-87$ \\
\hline KEVIN & KEVIN 1986-87 & UKE & UKE 1985-86 \\
\hline \multirow[t]{2}{*}{ KRIST } & KRISTIN 1985-86 & VANES & VANESSA $1985-1986$ \\
\hline & & VINCE & VINCE 1986-87 \\
\hline
\end{tabular}

